\title{
Verbal communication of the parturient nurse's dyad in the active phase of labor
}

\author{
Comunicação verbal da díade enfermeiro-parturiente na fase ativa do trabalho de parto \\ Comunicación verbal de la diade enfermera parturienta en la fase activa del trabajo de parto
}

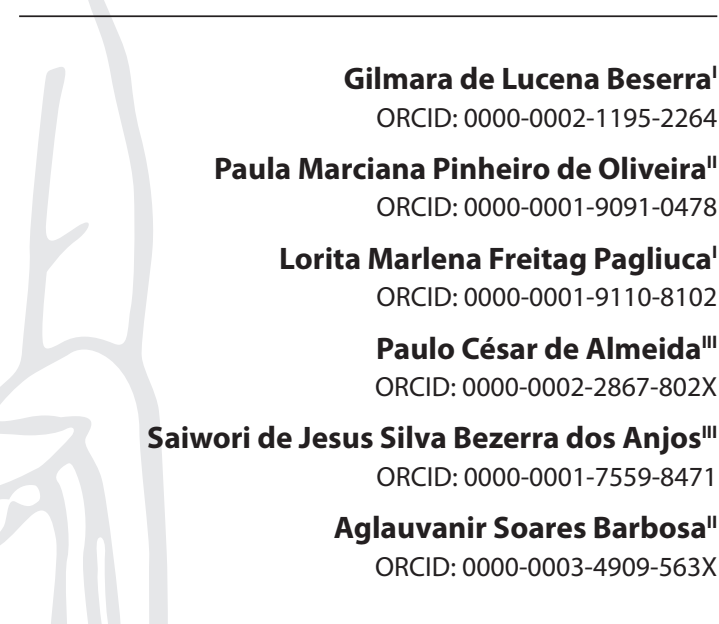

'Universidade Federal do Ceará. Fortaleza, Ceará, Brazil. "Universidade da Integração Internacional da Lusofonia Afro-Brazileira. Redenção, Ceará, Brazil. "'Universidade Estadual do Ceará. Fortaleza, Ceará, Brazil.

How to cite this article:

Beserra GL, Oliveira PMP, Pagliuca LMF, Almeida PC, Anjos SJSB, Barbosa AS. Verbal communication of the parturient nurse's dyad in the active phase of labor. Rev Bras Enferm. 2020;73(5):e20190266. doi: http://dx.doi.org/10.1590/0034-7167-2019-0266

\section{Corresponding author: \\ Gilmara de Lucena Beserra \\ E-mail: gilmaralucenaufc@gmail.com}

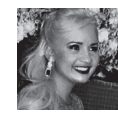

EDITOR IN CHIEF: Antonio José de Almeida Filho ASSOCIATE EDITOR: Fátima Helena Espírito Santo

\begin{abstract}
Objectives: to analyze verbal communication between the nurse and the parturient during the active phase of labor in two Lusophone countries. Methods: quantitative analytical study. Sample of 709 interactions between nurses and parturients using verbal communication during the active phase of labor in Brazil and Cape Verde. The following variables were analyzed: companion, conative vocative, conative imperative, emotive/ expressive and referential/context functions, contact/channel and code. Results: the absence of interaction predominated in most of the variables analyzed during the active phase of labor in both countries. In Cape Verde all interactions occurred during the absence of the companion. Conclusions: considering the social and cultural aspects of each country, nurses need to develop skills to communicate verbally with the parturient, offering a better interaction during the parturition process.

Descriptors: Communication; Obstetric Nursing; Labor; Natural Childbirth; Nurses.
\end{abstract}

\section{RESUMO}

Objetivos analisar a comunicação verbal entre enfermeiro e parturiente durante a fase ativa do trabalho de parto em dois países lusófonos. Métodos: estudo analítico quantitativo. Amostra com 709 interações utilizando comunicação verbal de enfermeiros e parturientes na fase ativa do trabalho de parto no Brasil e Cabo Verde. Analisaram-se as variáveis: acompanhante, funções conativa vocativa, conativa imperativa, emotiva/expressiva, referencial/contexto, contato/canal e código. Resultados: predominou ausência de interações na maioria das variáveis analisadas na fase ativa do trabalho de parto nos dois países. Em Cabo Verde, todas as interações foram estabelecidas com a ausência do acompanhante. Conclusões: considerando os aspectos sociais e culturais de cada país, os enfermeiros precisam desenvolver habilidades para comunicarem-se verbalmente com as parturientes, oferecendo a elas melhor interação no processo de parturição.

Descritores: Comunicação; Enfermagem Obstétrica; Trabalho de Parto; Parto Normal; Enfermeiras e Enfermeiros.

\section{RESUMEN}

Objetivos: analizar la comunicación verbal entre enfermero y parturienta durante la fase activa del trabajo de parto en dos países lusófonos. Métodos: estudio analítico cuantitativo. Muestra con 709 interacciones utilizando comunicación verbal de enfermeros y parturientas en la fase activa del trabajo de parto en Brasil y Cabo Verde. Se analizaron las variables: acompañante, funciones conativa/ vocativo e imperativo, emotiva/expresiva, referencial/ contexto, contacto/canal y código. Resultados: predominó ausencia de interacciones en la mayoría de las variables analizadas en la fase activa del trabajo de parto en los dos países. En Cabo Verde, todas las interacciones han sido establecidas con la ausencia del acompañante. Conclusiones: considerando los aspectos sociales y culturales de cada país, los enfermeros necesitan desarrollar habilidades para se comunicaren verbalmente con las parturientas, ofreciéndoles mejor interacción en el proceso de parturición.

Descriptores: Comunicación; Enfermería Obstétrica; Trabajo de Parto; Parto Normal; Enfermeras y Enfermeros. 


\section{INTRODUCTION}

Childbirth in the physiological and natural context, without medicalization and interventions, allows women to experience the moment in a more natural and human way, which stimulates the production of hormones spontaneously, within the physiology of the parturition process ${ }^{(1)}$.

Humanized support with effective and respectful communication improves the parturition process as well as the woman's feelings of control, thus increases confidence in her own strength and ability to give birth. This reduces the need for obstetric intervention and improves women's experience during labor ${ }^{(2)}$.

The embracement of the parturient by the nursing team enhances humanized care, but this contribution will only be effective when all are qualified for such act ${ }^{(3)}$. In this context, it is relevant to analyze the communication in the parturitive setting, as it must be constructive in the care process.

Communication is a powerful embracing and caring tool which facilitates building a trusting relationship. It is essential to know the elements that constitute the process in order to be effective and efficient, and thus achieve the objectives expected by the interlocutors. Therefore, a true connection between professionals and patients is expected, contributing to provide humanized and nurturing care, especially during labor, when the woman is vulnerable and fragile ${ }^{(4)}$.

In healthcare, communication occurs in different ways. All are extremely relevant to good care practice, as they are related to the various areas and scenarios of healthcare, whether in Brazil or in other members of the Community of Portuguese Language Countries (CPLP), such as Cape Verde. Routinely the nurse faces the need to communicate. It is his role to act in order to understand his patients in different cultural, social, and intellectual contexts, thus justifying the research. This study proceeds from the academic master's degree from the Universidade da Integração Internacional da Lusofonia Afro-Brasileira (UNILAB), which aims to disseminate and produce knowledge in a universal way, thereby contributing to economic, cultural, social and health development of Brazil and the other CPLP countries.

Among the types of communication, there are verbal and nonverbal. Verbal communication, according to the language functions theory, happens through the use of six elements: sender, receiver, context, message, code and contact $^{(5)}$ in all assistance contexts Specifically, in labor, nurse-parturient and parturientnurse communication contribute to the qualification of obstetric care in an institutional setting.

\section{OBJECTIVES}

To analyze the verbal communication of the nurse-parturient dyad during the active phase of labor in two Lusophone countries.

\section{METHODS}

\section{Ethical aspects}

Ethical precepts were respected according to the 466/12 Resolution of the National Commission for Research Ethics (CONEP) ${ }^{(6)}$, with the ethics committee approval under opinion 1,939,715. In Cape Verde, the National Health Research Committee approved the study under the terms of article 9 of Decree-Law No. $26 / 2007^{(7)}$. After invitation and acceptance to participate in the study, each participant signed the free and informed consent form (TCLE).

\section{Design, study location and period}

Analytical, quantitative study conducted in two scenarios (Brazil and Cape Verde). The study was conducted in a Natural Birth Center (NBC) located in a municipality in the metropolitan region of Fortaleza - CE (Brazil) and in a maternity hospital located on Santiago Island in Cape Verde (Africa). Both provide a benchmark for obstetric care. The NBC provides secondary health care to pregnant women, parturients and newborns with medical, and nursing staff (obstetric nurses and nursing technicians), and occupational therapists. The maternity hospital on Santiago Island provides secondary health care to parturients and newborns across the country, with medical staff and obstetric nurses. It is important to highlight that the service does not have the presence of nursing technicians. The data collection occurred from March to August of 2017 in both countries.

\section{Population or sample; inclusion and exclusion criteria}

The study population consisted of parturient and obstetric nurses. The study included parturients older than 18 years in the active labor stage without obstetric complications; as well as nurses working in obstetric care in Brazil and Cape Verde. Parturients who needed cesarean delivery or those in the expulsion stage were excluded. In Cape Verde, parturients who spoke Creole and did not communicate in Portuguese were excluded, given the difficulty for the researcher to understand the Creole language, native language of some African countries.

The sample consisted of the number of nurse-parturient and parturient-nurse verbal interactions during the active phase of labor.

\section{Data collection and Study protocol}

The data collection instrument followed Jakobson's theoretical framework, which highlights the importance of the circumstances in which the verbal communication occur ${ }^{(5)}$ according to the variables indicating the sender of the message, as well as the functions that were classified into: vocative conative, imperative conative, emotive/expressive, referential/contextual, contact or channel, and code. The instrument is called Nursing Verbal Communication Analysis Form (FACOVE), already validated in previous research ${ }^{(8)}$.

Conative functions are characterized by influencing or convincing, using vocatives, interjections, and imperative sentences, while the emotive/expressive function expresses an attitude towards the transmitted message. The referential/context function focuses on an objective and clear message about the verbal context. Contact/channel refers to a material channel between the sender and the receiver of the message, while code is the common message between sender and receiver ${ }^{(8)}$.

Data collection occurred after presentation of the study and signature of the TCLE by participants in both countries. Once accepted, the analysis of interactions began throughout the active stage of women's labor by completing the data collection instrument.

The instrument completion occurred in ten-minute intervals, that is, every ten minutes, new instruments were completed according to 
the interactions observed between the participants. It was recorded all the moments of verbal communication between nurse and parturient and vice versa during the active stage of the parturient labor. In the absence of communication, the option "absent" was marked. Data collection was interrupted at the end of the active stage of labor or when cesarean delivery was needed. The active stage of childbirth was chosen due to its long duration and its specificities, which allows to analyze the communication process.

Data were collected by the researcher in both countries; Initially, in Brazil, with the support of nursing undergraduates, qualified in communication theory and collection instruments, through prior reading of the theoretical framework and meetings to clarify doubts. In Cape Verde, the data was sampled by the main researcher.

\section{Analysis of results and statistics}

Data was organized in simple and crossed tables; For the analysis of the proportions between Brazil and Cape Verde, the chi-square and likelihood ratio tests were used. For inferential analysis, it was considered statistically significant those with $p$ value $<0.05$.

\section{RESULTS}

Altogether, in both countries, 709 dialogues were observed during verbal communication between study participants.

Table 1 shows the number of interactions according to the verbal communication between the professional nurse and the parturient from both countries.

Table 1 - Distribution of the number of interactions between nurses and parturients according to Verbal Communication, Maracanaú, Ceará, Brazil; and Beach, Cape Verde, 2017

\begin{tabular}{|c|c|c|c|c|c|}
\hline \multirow{2}{*}{ Variable } & \multicolumn{2}{|c|}{ Brazil } & \multicolumn{2}{|c|}{ Cape Verde } & \multirow{2}{*}{$\stackrel{p}{p}$ value $^{* *}$} \\
\hline & $\mathbf{n}$ & $\%$ & $\mathbf{n}$ & $\%$ & \\
\hline Sender & & & & & $<0.0001$ \\
\hline Nurse to parturient & 258 & 43.7 & 67 & 56.3 & \\
\hline Absent & 332 & 56.3 & 52 & 43.7 & \\
\hline Conative vocative function & & & & & $<0.0001^{1 * * *}$ \\
\hline Indicates action mode & 194 & 32.9 & 34 & 28.6 & \\
\hline Requests information/orientation & 39 & 6.6 & 26 & 21.8 & \\
\hline Requests suggestion & 20 & 3.4 & 6 & 5.0 & \\
\hline Agrees & 5 & 0.8 & 1 & 0.8 & \\
\hline Absent & 332 & 56.3 & 52 & 43.7 & \\
\hline Imperative conative function & & & & & $<0.0001$ \\
\hline Give orientation & 217 & 36.8 & 24 & 20.2 & \\
\hline Give suggestion & 41 & 6.9 & 35 & 29.4 & \\
\hline Does not agree & - & - & 8 & 6.7 & \\
\hline Absent & 332 & 56.3 & 52 & 43.7 & \\
\hline \multicolumn{6}{|l|}{ Emotive/expressive function ${ }^{(1)^{*}}$} \\
\hline 1. Solidarity & 35 & 5.9 & 15 & 12.6 & 0.009 \\
\hline Absent & 555 & 94.1 & 104 & 87.4 & \\
\hline 2. Satisfaction & 30 & 5.1 & 16 & 13.4 & 0.001 \\
\hline Absent & 560 & 94.9 & 103 & 86.6 & \\
\hline 3. Tranquility & 142 & 24.1 & 19 & 16.0 & 0.054 \\
\hline Absent & 448 & 75.9 & 100 & 84.0 & \\
\hline 4. Empathy & 74 & 12.5 & 13 & 10.9 & 0.624 \\
\hline Absent & 516 & 87.5 & 106 & 89.1 & \\
\hline 5. Apathy & 3 & 0.5 & 4 & 3.4 & 0.004 \\
\hline Absent & 587 & 99.5 & 115 & 96.6 & \\
\hline 6. Others & 1 & 0.2 & 1 & 0.8 & $0.280^{1 * * * * x}$ \\
\hline Absent & 589 & 99.8 & 118 & 99.2 & \\
\hline
\end{tabular}

\begin{tabular}{|c|c|c|c|c|c|}
\hline \multirow{2}{*}{ Variable } & \multicolumn{2}{|c|}{ Brazil } & \multicolumn{2}{|c|}{ Cape Verde } & \multirow{2}{*}{$\underset{\text { value }^{* *}}{p}$} \\
\hline & $\mathbf{n}$ & $\%$ & n & $\%$ & \\
\hline Referential/Context & & & & & $<0.0001^{1 * * *}$ \\
\hline Treatment & 145 & 24.6 & 36 & 30.3 & \\
\hline Prevention & 30 & 5.1 & 19 & 16.0 & \\
\hline Personal matters & 7 & 1.2 & 6 & 5.0 & \\
\hline Daily matters & 6 & 1.0 & 3 & 2.5 & \\
\hline Others & 70 & 11.9 & 3 & 2.5 & \\
\hline Absent & 332 & 56.3 & 52 & 43.7 & \\
\hline \multicolumn{6}{|l|}{ Contact/Channel ${ }^{(1)^{*}}$} \\
\hline Hearing & 194 & 32.9 & 67 & 56.3 & $<0.0001$ \\
\hline Absent & 396 & 67.1 & 52 & 43.7 & \\
\hline Touch & 130 & 22.0 & 1 & 0.8 & $<0.0001$ \\
\hline Absent & 460 & 78.0 & 118 & 99.2 & \\
\hline Vision & 116 & 19.7 & 67 & 56.3 & $<0.0001$ \\
\hline Absent & 474 & 80.3 & 52 & 43.7 & \\
\hline Code & & & & & 0.001 \\
\hline Common speech & 235 & 39.8 & 67 & 56.3 & \\
\hline Technical language & 23 & 3.9 & - & - & \\
\hline Absent & 332 & 56,3 & 52 & 43,7 & \\
\hline
\end{tabular}

Table 2 - Distribution of the number of interactions of Parturients according to Verbal Communication, Maracanaú, Ceará, Brazil; and Beach, Cape Verde, 2017

\begin{tabular}{|c|c|c|c|c|c|}
\hline \multirow{2}{*}{ Variable } & \multicolumn{2}{|c|}{ Brazil } & \multicolumn{2}{|c|}{ Cape Verde } & \multirow{2}{*}{$\underset{\text { value }^{* *}}{p}$} \\
\hline & $\mathbf{n}$ & $\%$ & $\mathbf{n}$ & $\%$ & \\
\hline Sender & & & & & 0.012 \\
\hline Parturient to nurse & 258 & 43.7 & 67 & 56.3 & \\
\hline Absent & 332 & 56.3 & 52 & 43.7 & \\
\hline Conative vocative function & & & & & $<0.0001$ \\
\hline Indicates action mode & 52 & 8.8 & 18 & 15.1 & \\
\hline $\begin{array}{l}\text { Requests information/ } \\
\text { orientation }\end{array}$ & 110 & 18.6 & 29 & 24.4 & \\
\hline Requests suggestion & 14 & 2.4 & 20 & 16.8 & \\
\hline Agrees & 83 & 14.1 & - & - & \\
\hline Absent & 331 & 56.1 & 52 & 43.7 & \\
\hline Imperative conative function & & & & & 0.025 \\
\hline Give orientation & 104 & 17.6 & 21 & 17.6 & \\
\hline Give suggestion & 133 & 22.5 & 42 & 35.3 & \\
\hline Does not agree & 22 & 3.7 & 4 & 3.4 & \\
\hline Absent & 331 & 56.1 & 52 & 43.7 & \\
\hline Emotive/expressive function ${ }^{(1)}$ & & & & & \\
\hline 1. Solidarity & 3 & 0.5 & 6 & 5.0 & $0.001^{1 * * *}$ \\
\hline Absent & 587 & 99.5 & 113 & 95.0 & \\
\hline 2. Satisfaction & 3 & 0.5 & 12 & 10.1 & $<0.0001$ \\
\hline Absent & 587 & 99.5 & 107 & 89.9 & \\
\hline 3. Tranquility & 102 & 17.3 & 12 & 10.1 & 0.051 \\
\hline Absent & 488 & 82.7 & 107 & 89.9 & \\
\hline 4. Empathy & 7 & 1.2 & 13 & 10.9 & $<0.0001$ \\
\hline Absent & 583 & 98.8 & 106 & 89.1 & \\
\hline 5. Others & 80 & 13.6 & - & - & $<0.0001$ \\
\hline Absent & 510 & 86.4 & 119 & 100.0 & \\
\hline 6. Sadness & 34 & 5.8 & 1 & 0.8 & 0.024 \\
\hline Absent & 556 & 94.2 & 118 & 99.2 & \\
\hline 7. Apathy & 3 & 0.5 & 20 & 16.8 & $<0.0001$ \\
\hline Absent & 587 & 99.5 & 99 & 83.2 & \\
\hline 8. Others & 30 & 5.1 & 3 & 2.5 & 0.226 \\
\hline Absent & 560 & 94.9 & 116 & 97.5 & \\
\hline Referential/Context & & & & & $<0.0001$ \\
\hline Treatment & 134 & 22.7 & 32 & 26.9 & \\
\hline Prevention & 34 & 5.8 & 19 & 16.0 & \\
\hline Personal matters & 11 & 1.9 & 10 & 8.4 & \\
\hline Daily matters & 9 & 1.5 & 4 & 3.4 & \\
\hline Others & 69 & 11.7 & 2 & 1.7 & \\
\hline Absent & 333 & 56.4 & 52 & 43.7 & \\
\hline
\end{tabular}


Table 2 (concluded)

\begin{tabular}{|c|c|c|c|c|c|}
\hline \multirow{2}{*}{ Variable } & \multicolumn{2}{|c|}{ Brazil } & \multicolumn{2}{|c|}{ Cape Verde } & \multirow{2}{*}{$\underset{\text { value }^{* *}}{p}$} \\
\hline & $\mathbf{n}$ & $\%$ & $\mathbf{n}$ & $\%$ & \\
\hline \multicolumn{6}{|l|}{ Contact/Channel $^{(1)^{*}}$} \\
\hline Hearing & 199 & 33.7 & 67 & 56.3 & $<0.0001$ \\
\hline Absent & 391 & 66.3 & 52 & 43.7 & \\
\hline Touch & 92 & 15.6 & - & - & $<0.0001$ \\
\hline Absent & 498 & 84.4 & 119 & 100.0 & \\
\hline Vision & 128 & 21.7 & 67 & 56.3 & $<0.0001$ \\
\hline Absent & 462 & 78.3 & 52 & 43.7 & \\
\hline Code & & & & & 0.003 \\
\hline Common speech & 241 & 40.8 & 67 & 56.3 & \\
\hline Technical language & 17 & 2.9 & - & - & \\
\hline Absent & 332 & 56.3 & 52 & 43.7 & \\
\hline
\end{tabular}

As exposed in the nurse's verbal communication with the parturient, there is a predominance of lack of interactions in most variables, such as the vocative conative function. According to the data $(p<0.0001)$, the lack of interaction of the nurses prevailed in Brazil (56.3\%). In Cape Verde, most nurses interacted with the parturients (56.3\%).

Further on, Table 2 presents data on the distribution of the number of instances of communication of the parturients with the nurses.

Regarding the verbal communication of the parturient with the nurse, the absence of interactions in most variables also prevailed, with the greatest absence been in the Brazilian scenario (Table 2).

\section{DISCUSSION}

The absence of verbal communication by the obstetrician nurse figure during labor assistance, in many services, occurs due to the lack of qualification of these professionals and functions directed to administrative activities, the reduced number of professionals in the team or the flaws in communicative aspects ${ }^{(9)}$. In this process, communication should occur through dialogue with easily understood words, in which nurses and parturients share meanings and emotions that become common to them when they experience childbirth ${ }^{(10)}$.

The actions used by the professionals assisting the parturient women demonstrate that noninvasive and non-pharmacological methods are efficient and widely used; also, other strategies employed in care practice are offering parturients the free choice of position during labor, encouraging the use of bathing, walking, and aspersion bath ${ }^{(11)}$. In Brazil, it was observed, through the analysis of the verbal communication interactions of obstetric nurses, that they offered more attention, safety for parturients, and non-pharmacological methods for pain relief.

The obstetric nurse is the professional who is present in the labor monitoring alongside the woman, stimulating and offering security, encouragement, and autonomy, besides being essential in the early detection of complications that may arise during labor. The professional support the birth process and encourages the active participation of the woman with as few interventions as possible so that the parturient can be the protagonist in this moment.

A survey conducted with women at Bwaila Maternity Hospital in Lilongwe, Malawi evaluated the maternity care (prenatal, intrapartum, and postnatal), in which women recognized that it was their responsibility to communicate through questions and clarify their concerns when needed. The healthcare professional must understand that answering the patients' questions and concerns is part of the treatment process ${ }^{(12)}$. It was found in this study, about the characterization of the sender between parturient and nurse, that women appear as the only sender in both countries, in the observed relations. The parturients communicated with the nurses whenever they wanted or expressed requests or doubts clarification.

In the Brazilian context, women have the right to choose the person who will accompany them throughout the parturition process $^{(13)}$. In Brazil, most interactions between nurse and parturient occurred with the presence of the companion. In the country, the Companion Law n⿳0 11.108 / 2005 states that obstetric services, public or private, must allow the presence of a companion during the labor, delivery, and postpartum.

In Cape Verde, the reality concerning the presence of the companion differs from Brazil. There, the presence of the companion is not allowed either in the process of labor, delivery, or birth, so verbal communication was established without the presence of the companion. This can increase women fear and insecurity during labor which may result in a longer process.

Obstetric nurses in Cape Verde reported that childbirth humanization strategies were implemented in 2015 to encourage the presence of the companion; however, the permission of the companion was terminated months later. According to reports, this occurred due to the setting lack of space and infrastructure to receive one more person in the pre-labor/labor rooms and the lack of interest of family, friends, and parents to accompany this important moment.

For considering women as a singular person with sexual and reproductive rights, it is necessary to value their life experiences and cultural aspects since prenatal consultations, seeking to better orient them to the experience a normal birth ${ }^{(14)}$. Certainly, if women received important information previously to labor, they would enter the obstetric facilities more confident and secure. As a result, they could establish better relations and better communication with the entire professional team.

Research conducted with health professionals focused on communication during labor states that communication may be limited in situations where women demonstrate insecurity and fear. It is important to have an open communication and allow parental involvement for the natural progress of childbirth. Participants described their efforts to engage women and their partners, using effective communication to inform choices facilitating decisions whenever possible ${ }^{(15)}$.

Regarding communication, the treatment shown in health care context ${ }^{(8)}$, in the active labor process, proved to be the moment of greatest interaction presented among study participants, in addition to clarifying doubts, fear, and emotions for the parturient. Thus, in relation to the referential/ context, the action most found in the interactions between nurses and parturients was related to treatment in Brazil and Cape Verde. Brazilian and Cape Verdean parturients dialogued with nurses about their labor process; moreover, the verbalization of feelings expressed during the parturition process - such as the desire to vomit and the desire to push during childbirth - was reported by the observed parturients. Another issue related to the treatment mentioned by the parturients was about the loss of amniotic fluid (AL). They asked about the risks this could bring to her and the baby.

Research on women's decision on labor indicates that the resolutions of the parturient depend on her receiving unbiased and 
balanced information regarding all possible outcomes of childbirth. Subjects cannot accurately assess risks or assign personal value to results in the absence of complete and unbiased information, which compromises their ability to make better decisions. Thus, health professionals are required to pay more attention, to take visual and auditory care in order to identify the women's needs ${ }^{(16)}$. Guiding them about labor (treatment) requires from the obstetric nurse the use of sensory communication channels.

It is necessary that nurses, in the clinical period of delivery, use sensory communication channels such as hearing and vision, which will be determining factors for accomplishing good care. The professional must value the parturient history, which can be a facilitator in the experience of childbirth, therefore respecting each woman's individuality ${ }^{(17)}$. The study showed, with the support of statistically significant data, that hearing was the most used contact/channel between nurses and parturients in Brazil, and in Cape Verde.

Language is the main communication tool which can be used to validate information concerning given subjects in all contexts ${ }^{(5)}$. In this study, it is noteworthy in this opportunity, the importance of providing information/guidance to these women regarding labor still during prenatal consultations. In this context, verbal communication becomes indispensable for the process of recognizing the parturient's needs, expressing her acceptance and respect.

Descriptive study related to women's perception of their communication with health professionals highlights that the facilitating factor of communication between professionals and patients is good interaction between them, with good understanding, cordiality, sympathy, and respect. On the other hand, factors that inhibit communication include verbal abuse of women, healthcare providers failure to answer patient's questions, language barriers, and poor communication quality ${ }^{(18)}$. Therefore, in the code used between nurses and parturients, the common speech prevailed in both countries, thus avoiding technical terms. This is a positive point of the interactions that facilitates the parturient's understanding of the orientations. In terms of "code", between parturient and nurse, the common speech also prevailed in both scenarios. The fact that similar language prevailed in both countries demonstrates that the use of common words and not technical terms in communication is a facilitating item for the parturients' learning and interaction with the professionals.

The intersubjectivity that occurs in communicative relations needs to be valued, and the communicational events need to be recognized. Thinking communication as a unique experience that brings people together and facilitates dialogue will help us understand the production of meaning as a sensitive activity, performed by active and conscious subjects ${ }^{(19)}$. Regarding the analyzed variables with different results in the nurse-parturient and parturient-nurse interactions, as far as the vocative conative function is concerned, the way of indicating action was the most found in both countries between parturient nurses. Through the action mode, it was observed that nurses made requests to the parturients related to the use of the gown (hospital garment) offered by the service at the time of admission to the Labor and Delivery rooms, and asked the patient to urinate, if desired, prior to the vaginal examination to check for uterine dilation. The nurses guided the parturients from the moment of admission on the importance of the rocking chair and the swiss ball as auxiliary methods for the labor evolution until the beginning of the expulsive stage.
It is necessary to offer the woman attentive, respectful, and nurturing care as it is a time of many doubts, fears, and uncertainties. It is necessary that the professional offers fond and humanized care, respecting the importance of the communication process, aiming to make birth a positive, pleasant, and satisfactory experience for women, thus preserving the mother-infant pair ${ }^{(10-11)}$.

It is incumbent on the professionals who accompany the parturient to understand the importance of communication in their care practice, listening carefully to their needs, valuing their life history, requesting important information related to labor, thus strengthening the bonds of trust between the multi-professional team and the parturient ${ }^{(17)}$. Cape Verdean obstetric nurses have significantly requested information from parturients - for example, where they lived, questions about food intake and environmental comfort (temperature). During the obstetric anamnesis, the nurses provided the parturient with important information to ensure her comfort and holistic care. They also asked if they were comfortable with the environment temperature. The room in which they were located were air-conditioned rooms with a natural light environment.

The obstetric nurse, through their suggestions during the care practice, may offer the patient possibilities for better quality and autonomous parturition process ${ }^{(20)}$. Establishing effective verbal communication between the subjects in the conative mode is essential, as well as analyzing the transmitted verbal communication properties. According to the verbal communication theory used in the study, it is important to verify that the verbal message received is real.

In this communicative process, it is significant to consider the participants' contact during the speech act; the common code between them and the singularities of the encoding and decoding process, and the whole message context ${ }^{(21)}$. Thus, imperative conative function between parturient and nurse prevailed in the study by suggesting care in both countries. This is more noticeable in Cape Verde where it is prevalent. It is also an important option for health care and promotion.

A previous study on patients' satisfaction with received care shows that women grant value to the following aspects: care sensation, health care professionals' attitude, and sensitivity, creativity, and attention to culture and ethnicity, good communication, and given guidance ${ }^{(22)}$. Among the orientations given, the most observed was related to ambulation. In both Brazil and Cape Verde, parturients were motivated to walk aiming a faster evolution of labor. However, in Cape Verde, the parturients resisted the orientation. This rejection is believed to be due to the lack of information regarding the benefits of ambulation in active labor. In Brazil, considering the imperative conative function, most professionals provided the parturients with guidance advising them about the importance of ambulation, as well as the use of the Swiss ball. In Cape Verde, "offering suggestion" was the most used among participants in the interactions recorded.

Caring and promoting health also has individual expressions and feelings in the act of verbally communicating. The purpose of emotive and/or expressive verbal communication is to express emotions, feelings, moods, aiming a direct expression of the person who speaks in relation to that or to whom speaks. This function refers in most communication to the message sender ${ }^{(23)}$. Therefore, in the study, the most identified emotive/expressive function between the nurse and the parturient was "tranquility". 
Brazilian and Cape Verdean nurses, in their initial interactions with the parturient, addressed the issue in a calm and welcoming manner, emphasizing the importance of women's participation in the active labor and in the assistance itself. Due to the predominance of this issue, it was observed that professionals are concerned in helping women to be more participative, cooperative, and included in the childbirth context. Between parturient and nurse, "tranquility" prevailed in Brazil; and "apathy" in Cape Verde.

A systematic review of mixed methods brought a UK study on interventions to improve effective communication between care staff (midwives) and healthy women in labor, in which it significantly improved in postpartum hemorrhage scenarios after training with patient-actor at local hospitals ${ }^{(24)}$. A study in Ghana found that women's care experience is affected by a wide range of factors that must take into account women's perspective on the care they need, as well as the feedback on the services they receive, emphasizing that nursing education should strengthen communication/relation skills with these women ${ }^{(25)}$.

In this context of sharing of sensitivities, communication should be considered an essential component to improve the relationship between women and health professionals. Nurses are perceived as influential actors in the practice of respectful maternal care, as they develop diverse roles, acting as caregivers, educators, and decision-makers ${ }^{(12)}$.

In addition to this, there is the fact that nurses positively contribute to the obstetric care transformation, making it more humanized, due to its sensitivity before the use of its technical competence to relate to the parturients in a nurturing and caring way.

Therefore, it can be observed that the obstetric nurse enables women to empowerment in the parturition experience by using good communication. Also, their important performance at the delivery moment contributes to humanization, and qualification of obstetric care, ensuing the parturient's satisfaction and safety.

\section{Study limitations}

During data collection in Cape Verde, the country's cultural and idiomatic issues stood out. Some parturients spoke the Creole dialect, which hindered communication with the researcher who wasn't fluent in the idiom, so it was impossible to present the study and apply the TCLE. In the Brazilian scenario, the limitation is related to the difficulty that the researcher had to explain the study and the TCLE for parturients who were in the active stage of labor.

\section{Contribution to the nursing field}

The study significantly contributes to nursing obstetric care, considering that the results show the need and relevance of developing strategies to promote knowledge regarding verbal and nonverbal communication in labor and birth scenario in Brazil and in Cape Verde, according to care and cultural singularities of both Lusophone countries.

\section{CONCLUSIONS}

The verbal communication between parturients and nurses is characterized in two ways according to the analysis performed: the data that were similar in both countries and the data that were divergent, as in the emotional function used by women in both countries. Regarding the companion, it is noteworthy that he was identified in Brazil. However, in Cape Verde, this practice does not exist.

It is concluded that it is essential to enhance the range of skills for effective use of verbal communication in order to qualify obstetric care. The practices used in parturient care demonstrated that noninvasive and non-pharmacological methods facilitate communication in this care context.

The study evidenced the need to implement in Cape Verde strategies to encourage and guide obstetric nurses and parturient about the importance of companion in the parturition process. The relevance of communication in the care process of the obstetric scenario is evidenced in both countries, in order to provide improvement in the care provided. In this sense, it is suggested to emphasize the importance of the verbal communicative process for this Lusophony health scenario.

\section{REFERENCES}

1. Ramos WMA, Aguiar BGC, Conrad D, Pinto CB, Mussumeci PA. Contribution of obstetric nurse in good practices of childbirth and birth assistance. Rev Pesqui: Cuid Fundam. 2018;10(1):173-9. doi: 10.9789/2175-5361

2. Bohren MA, Hofmeyr GJ, Sakala C, Fukuzawa RK, Cuthbert A. Continuous support for women during childbirth. Cochrane Database System Reviews 2017;7. doi: 10.1002/ 14651858.CD003766.pub6

3. Silva Ú, Fernandes BM, Paes MSL, Duque DAA. Nursing care experienced by women during the child-birth in the humanization perspective. Rev Enferm UFPE. 2016;10(4):1273-9.doi: 10.5205/reuol.8464-74011-1-SM.1004201614

4. Broca PV, Ferreira M de A. Communication process in the nursing team based on the dialogue between Berlo and King. Esc Anna Nery. 2015;19(3):467-474. doi: 10.5935/1414-8145.20150062

5. Jakobson R. Linguística e comunicação. São Paulo: Cultrix, 2010. 194 p.

6. Ministério da Saúde (BR). Conselho Nacional de Saúde. Resolução no 466 de 12 de dezembro de 2012 [Internet]. Brasília (DF): Ministério da Saúde. 2013[cited 2019 Jan15]. Available from: http://bvsms.saude.gov.br/bvs/saudelegis/cns/2013/res0466_12_12_2012.html

7. Cabo Verde. Ministério da Saúde. República de Cabo Verde. Decreto Lei №26 de 30 de julho de 2007 [Internet]. Cabo Verde: Ministério da Saúde. 2007[cited 2019 Jan15]. Available from: https://www.minsaude.gov.cv/index.php/legislacaoms/68-etica-comite-de-dl-26-2007/file 
8. Pagliuca LMF, Macêdo KNFC, Rebouças CBA, Almeida PC, Sampaio AFA. Validação das diretrizes gerais de comunicação do enfermeiro com o cego. Rev Bras Enferm. 2014;67(5):715-21. doi:10.1590/0034-7167.2014670507.

9. Almeida OSC, Gama ER, Bahiana PM. Humanization of childbirth. Revista Enfermagem Contemporânea. 2015;4(1):79-90. doi:10.17267/23173378rec.v4i1.456.

10. Barros LM de. Comunicação sem anestesia. Intercom: Rev Bras Ciênci Comun. 2017;40(1):159-75. doi:10.1590/1809-5844201719.

11. Reis TR, Zamberlan C, Quadros JS, Grasel JT, Moro ASS. Obstetric Nurses: contributions to the objectives of the Millennium Development Goals. Rev Gaúcha Enferm. 2015;36(spe):94-101. doi: 10.1590/1983-1447.2015.esp.57393

12. Jolly $\mathrm{Y}$, Aminu M, Mgawadere F, van den Broek N. "We are the ones who should make the decision": knowledge and understanding of the rights-based approach to maternity care among women and healthcare providers. BMC Pregnancy Childbirth. 2019;19(1):19-42. doi:10.1186/s12884-019-2189-7

13. Rodrigues DP, Alves VH, Penna LHG, Pereira AV, Branco MBLR, Souza RMP. Non-compliance with the companion law as an aggravation to obstetric health. Texto Contexto Enferm. 2017;26(3):1-10. doi:10.1590/0104-07072017005570015

14. Vedam S, Stoll K, McRae DN, Korchinski M, Velasquez R, Wang J, et al. Patient-led decision making: Measuring autonomy and respect in Canadian maternity care. Patient Educ Counseling. 2018;1-9. doi: 10.1016/j.pec.2018.10.023

15. Rönnerhag $M$, Severinsson $E$, Haruna $M$, Berggren I. A qualitative evaluation of healthcare professionals' perceptions of adverse events focusing on communication and teamwork in maternity care. J Adv Nurs. 2019;75(3):585-93. doi:10.1111/jan.13864

16. Miller YD, Holdaway W. How communication about risk and role affects women's decisions about birth after caesarean. Patient Educ Counseling. 2019;102(1):68-76.doi: 10.1016/j.pec.2017.09.015

17. Oliveira JDG, Campo TNC, Souza FM de LC, Davim RMB, Dantas J da C. Obstetric nurses' perception in assistance to the parturient. Rev Enferm UFPE. 2016;10(10):3868-75. doi: 10.5205/reuol.9667-87805-1-ED1010201619

18. Madula P, Kalembo FW, Yu H, Kaminga AC. Healthcare provider-patient communication: a qualitative study of women's perceptions during childbirth. Reproduct Health. 2018;15(1):135-44. doi: 10.1186/s12978-018-0580-x

19. Barros LM. Comunicação sem anestesia. Intercom. 2017;40(1):159-175. doi:10.1590/1809-5844201719.

20. Dodou HD, Rodrigues DP, Guerreiro EM, Guedes MVC, Lago PN, Mesquita NS. The contribution of the companion to the humanization of delivery and birth: perceptions of puerperal women. Esc Anna Nery. 2014;18(2):262-9. doi:10.5935/1414-8145.20140038

21. Santee NR, Temer ACRP. Roman Jakobson's Linguistics: contributions to communication studies. Cient Ciênc Human Educ[Internet]. 2011 [cited 2019 Jan15];12(1):73-82. Available from: http://revista.pgsskroton.com.br/index.php/ensino/article/view/2890/2762

22. Jomeen J, Redshaw M. Ethnic minority women's experience of maternity services in England. J Ethnic Health. 2013;18(3):280-96. doi: $10.1080 / 13557858.2012 .730608$

23. Winch PG, Nascimento SS. The theory of communication by Jakobson: its marks in Portuguese language teaching. Estud Língua(gem) [Internet]. 2012[cited 2019 Jan15];10(2):220-236. Available from: http://periodicos2.uesb.br/index.php/estudosdalinguagem/article/ view/1196

24. Hang YS, Coxon K, Portela AG, Furuta M, Bick D. Interventions to support effective communication between maternity care staff and women in labour: a mixed-methods systematic review. Midwifery. 2018;59:4-16. doi: 10.1016/j.midw.2017.12.014

25. Afaya A. Qualitative study on women's experiences of intrapartum nursing care at Tamale Teaching Hospital (TTH), Ghana. J Caring Sci. 2017;6(4):303-14. doi: 10.15171/jcs.2017.029 